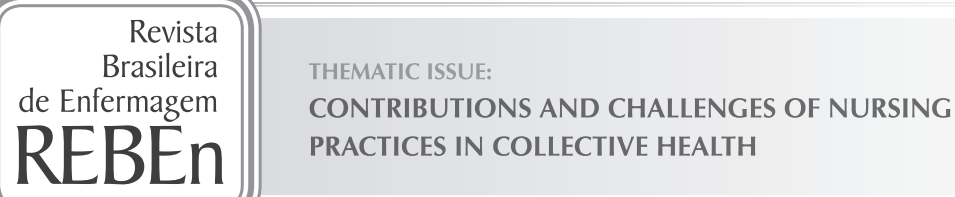

\title{
Permanent education in the vaccination room: what is the reality?
}

\author{
Educação permanente em sala de vacina: qual a realidade? \\ Educación permanente en sala de vacuna: ¿cuál es la realidad?
Jéssica Rauane Teixeira Martins', Bruna Gabrielly Pereira Alexandre', Valéria Conceição de Oliveira', Selma Maria da Fonseca Viegas' \\ 'Universidade Federal de São João del-Rei. Divinópolis, Minas Gerais, Brazil.
}

\section{How to cite this article:}

Martins JRT, Alexandre BGP, Oliveira VC, Viegas SMF. Permanent education in the vaccination room: what is the reality?. Rev Bras Enferm [Internet]. 2018;71(Suppl 1):668-76. [Thematic Issue: Contributions and challenges of nursing practices in collective health] DOI: http://dx.doi.org/10.1590/0034-7167-2017-0560

Submission: 08-07-2017 Approval: 12-13-2017

\begin{abstract}
Objective: To understand, from the perspective of the professional, the Permanent Education (PE) in the vaccination room in its real context. Method: Multiple holistic-qualitative case studies, based on Maffesoli's Interpretive Sociology with 56 participants from four microregions of the Western Extended Region of Minas Gerais State. Results: They present PE as infrequent and insufficient. They denote that the practical-theoretical experience with vaccine contributes to the work; the search for knowledge, starting from the professional itself; and the professional training fails to perform in the vaccination room. Final considerations: The notions of PE are linked to the daily needs of individuals and services, with indication of being interactive, periodic, in specific and non-global issues for better assimilation. Obstacles to the non-implementation of $\mathrm{PEH}$ are realized by the workload associated with insufficient human resources, the distance of the nurses from the vaccination room and the lack of support from the higher levels.
\end{abstract}

Descriptors: Permanent Education; Vaccination; Immunization; Nursing Staff; Nursing.

\section{RESUMO}

Objetivo: Compreender, sob a ótica do profissional, a Educação Permanente (EP) em sala de vacina em seu contexto real. Método: Estudo de casos múltiplos holístico-qualitativo, fundamentado na Sociologia Compreensiva do Cotidiano com 56 participantes de quatro microrregiões da Região Ampliada Oeste de Minas Gerais. Resultados: Apresentam a EP como pouco frequente e insuficiente. Denotam que a experiência prático-teórica com vacina contribui com o trabalho, a busca do conhecimento partindo do próprio profissional e a formação profissional falha para atuação em sala de vacina. Considerações finais: As noções de EP vêm atreladas às necessidades cotidianas individuais e dos serviços, com indicação de ser interativa, periódica, em temas pontuais e não globais para melhor assimilação. Os entraves para não realização da EPS se concretizam na sobrecarga de trabalho associada a recursos humanos insuficientes, o distanciamento do enfermeiro da sala de vacina e a falta de apoio das instâncias superiores.

Descritores: Educação Permanente; Vacinação; Imunização; Equipe de Enfermagem; Enfermagem.

\section{RESUMEN}

Objetivo: Comprender, bajo la óptica del profesional, la Educación Permanente (EP) en sala de vacuna en su contexto real. Método: Estudio de casos múltiples holístico-cualitativo, fundamentado en la Sociología Comprensiva del Cotidiano con 56 participantes de cuatro microrregiones de la Región Ampliada Oeste de Minas Gerais. Resultados: Presentan la EP como poco frecuente e insuficiente. Denotan que la experiencia práctico-teórica con vacuna contribuye con el trabajo, la búsqueda del conocimiento partiendo del propio profesional y la formación profesional falla para la actuación en sala de vacuna. Consideraciones finales: Los conceptos de EP están ligadas a las necesidades cotidianas individuales y de los servicios, con indicios de ser interactiva, periódica, en temas puntuales y no globales para una mejor asimilación. Los obstáculos para la no 
realización de la EPS se concretan en la sobrecarga de trabajo asociada a los recursos humanos insuficientes, el distanciamiento del enfermero de la sala de vacuna y la falta de apoyo de las instancias superiores.

Descriptores: Educación Permanente; Vacunación; Inmunización; Equipo de Enfermería; Enfermería.

\section{CORRESPONDING AUTHORＳelma Maria da Fonseca ViegasＥ-mail: selmaviegas@ufsj.edu.br}

\section{INTRODUCTION}

Permanent Education in Health (PEH) as a transformative strategy of health practices collaborates to break with the traditional paradigm that guides the training processes of health workers. "It is an instrument that aims at personal, social and cultural development and is centered in teaching-learning processes, in which the individual who learns himself is an active, autonomous agent and manager of his education"(1).

The historical milestones of PEH in Brazil refer to the few decades. As a pedagogical guideline, it became a public policy in the health area through Administrative Rule GM/MS No. 198/2004, which established the National Permanent Health Education Policy (NPHEP), as a strategy for the training and development of health workers ${ }^{(2)}$.

However, even as public policy, "Permanent Health in Education is an ambitious and necessary challenge" ${ }^{\prime(3)}$. It should focus on the world of work and be based on the meaningful learning of health production collectives, since workers occupy a unique place in SUS (Unified Health System): that of people with desire and implication ${ }^{(4)}$. The daily work problems and the pre-existing knowledge and experiences of health production collectives should be considered. "The resolution of these problems does not always involve educational activities for health professionals, but undoubtedly the development of workers is crucial when changing the health model and improving the quality of care"(5).

Because vaccination rooms are complex and dynamic environments, PE is paramount. The complexity is due to the fact that knowledge in vaccination is constantly changing. In recent years, there have been several changes in vaccination schedules, with the incorporation of new vaccines, in addition to the expansion of age groups on recommendation of vaccination. The norms are constantly modified/updated, requiring continuous training and permanent supervision of professionals who carry out activities in the vaccination rooms. In addition, we highlight the workload in Primary Health Care (PHC), as well as the obligation to maintain immunobiological quality and ensure safe vaccination ${ }^{(6-9)}$.

Given the complexity of the work in the vaccination room, an important aspect in the result of the effectiveness of the immunization, it is indispensable that the professionals go through constant processes of education. In this way, vaccination rooms are environments in which PEH is fundamental.

However, studies carried out in Brazil and abroad show the deficiencies in the training of workers who work in the vaccination room ${ }^{(8-12)}$. The updates made to the professionals are unsystematic and the standardized procedures recommended are not always performed in local instances, putting the conservation, handling and preparation of immunobiologicals as well as the control of immunopreventable diseases at risk ${ }^{(9,12)}$. Periodic assessment, continuous and permanent education, and response to training requirements, such as team motivation, help to remedy these barriers ${ }^{(10)}$.

Considering this context, it is questioned: how does the $\mathrm{PEH}$ occur in the daily work in vaccination rooms? What is the reality of $\mathrm{PE}$ for professionals working in the vaccination room and for the technical references in vaccination?

This study aims at understanding, from the perspective of the professional, Permanent Education in the vaccination room in its real context.

\section{METHOD}

\section{Ethical aspects}

This study was approved and developed through the guidelines and regulatory standards defined in Resolution CNS 466 of December 12, 2012. It is part of the Integrated Project, approved by the Research Program for the Brazilian Unified Health System (SUS) (PPSUS), Quality of the National Immunization Program in the Western Health Expanded Region, which is articulated and deployed in this research.

\section{Theoretical-methodological reference, type of study, sce- nario and research participants}

This is a qualitative study, outlined by the holistic multiple case study methodological framework ${ }^{(13)}$ and based on the theoretical framework of Maffesoli's Interpretive Sociology (14). Considering that it is in the context of the daily practices that $\mathrm{PE}$ is inserted in the vaccination room, it is opportune to launch the look of the Maffesoli's Interpretive Sociology on the object of study, since its purpose is to analyze what concerns about everyday life, lived experiences, beliefs and actions of the individuals in their relationship environments ${ }^{(14)}$, thus enabling the understanding of PE through the plurality of visions and experiences experienced by professionals and technical references in vaccination.

The scenario of the study consisted of the West Extended Region of Minas Gerais State, which is composed of 54 municipalities grouped in six health microregions (Itaúna, Pará de Minas, Formiga, Bom Despacho, Santo Antônio do Amparo/ Campo Belo, Divinópolis/Santo Antônio do Monte). Four microregions of health were included in this study: Divinópolis/ Santo Antônio do Monte, Itaúna, Pará de Minas, and Formiga, represented by seven municipalities. It is therefore about four cases defined by the four microregions, and had as its sole unit of analysis the "Permanent Education in the vaccination room", configuring it as a holistic study.

The number of cases considered necessary or sufficient in multiple case studies should take into account a discretionary 
judgment and not follow formulas. That is, the number of replications will be conditioned to the level of certainty that is desired to be obtained with the results of multiple $\operatorname{cases}^{(13)}$. In this study, this level was affirmed with data collection in the fourth microregion, giving $66.67 \%$ of the total of the six microregions of the Region. This result was confirmed by the saturation of the data by literal replication ${ }^{(13)}$, that is, by the similar results presented in the four cases and by the fact that the data collected were sufficient to meet the proposed method and objective.

Aiming to obtain representativity of different realities and so that the results can have external generalization capacity in qualitative research the municipalities were selected taking into account the following characteristics: population size, coverage of the Family Health Strategy (FHS), territorial extension and number of rooms. Of the municipalities selected, two are small, two medium and three large. Of these municipalities, two have $100 \%$ population coverage of FHS and the other five municipalities have population coverage of FHS less than 100\%. Among these municipalities, the number of vaccine rooms ranged from one to 35 vaccination rooms. As a scenario of the research, there were 25 rooms of the total of 340 rooms of the Extended Region West of Minas Gerais State (Memorandum).

56 health professionals who work or are referenced in the vaccination room participated in the study, being nine Nursing assistants, 17 Nursing technicians, 23 nurses and 07 technical references in immunization of the municipalities. Of the 56 , only two are males, the mean age is 37.6 years, and the age ranged from 22 years to 58 years. The mean time of operation in the vaccination room was 8.9 years, ranging from two weeks to 31 years of age. It was used as inclusion criterion the professional to act in the vaccination room. The approach of the participants of this study was in person at the health unit where it operates. After explaining the purpose of the research and agreeing to participate in the study, formal authorization was requested through the signing of the Informed Consent Term. Initially, the number of participants was not defined and the data collection was closed after identifying the literal replication in each case and the amount of the four cases ${ }^{(13)}$. After literal replication was verified, two interviews were carried out in each microregion, confirming the saturation of the data and determined the closure of the collection. To maintain the anonymity of the survey participants, respondents were identified by the letter $E$, followed by the consecutive numbering according to the microregion $(1,2,3$ or 4$)$ and the chronological sequence of the interviews.

\section{Collection, organization and analysis of data}

Data collection took place from June 2016 to May 2017 using an individual, open, intensive interview based on a semi-structured script, a technical visit to vaccination rooms and memos. The semi-structured script was previously tested, based on the following questions: 1 . Tell me about your experience in the vaccination room. 2. How do you feel working in the vaccination room? 3. What do you understand by Permanent Education (education for work)? 4. How does Permanent Education occur in your work environment? 5. In your opinion, what should Permanent Education be for your work in the vaccination room? 6 . Would you like to say anything else related to Permanent Education for your work in the vaccination room? 7. When did you last receive the vaccination room training? 8 . When did you start vaccine work, did you undergo any training?

The interviews took place in the professional's own workplace and were individually recorded and transcribed in their entirety and had an average duration of thirteen minutes. The data from the technical visits were recorded in memos as well as the impressions of the researchers during the interviews.

For data analysis, we used the Thematic Content Analysis proposed by Bardin ${ }^{(15)}$, obeying the analytic technique of crosssynthesis of the cases, in consonance with the methodological framework for the study of multiple qualitative holistic cas$\mathrm{es}^{(13)}$. Three thematic categories originated: Permanent Education in the vaccination room: what is the reality? Vaccination in daily life: frequent changes, difficulties and accountability point to Permanent Education; reality in the vaccination room: structure, organization, support and technical responsibility.

\section{RESULTS}

The 25 vaccination rooms in the Western Region of Minas Gerais State visited showed deficits in relation to $\mathrm{PEH}$ to the professionals that are inserted in them. At the technical visits, it was possible to identify what interferes with the implementation of PEH, being obstacles: the work overload associated with insufficient human resources; the nurse's distance from the vaccination room; and the lack of support from higher levels (Memorandum).

Another aspect very evident in the technical visits was the role of the nurse, as technical reference of the vaccination room. Most of the time, the nurse is not present in the vaccination room, does not supervise and is not always identified by nursing technicians as a reference in case of doubt (Memorandum). The analysis of the interviews corroborates this reality.

The category Permanent Education in the vaccination room: what is the reality? It is organized into three subcategories: Notions of Permanent Education; Education, qualification and training: means for professional education in service; and The scope of Permanent Education in the vaccination room: frequency, participation and daily obstacles.

\section{Notions of Permanent Education}

The interviewees understand $\mathrm{PEH}$ as an education that starts from the need of the service, as a way to update knowledge and seek improvements:

Permanent education is that education that comes from the need of the service. $\left(\mathrm{E}_{1-1}\right)$

Permanent education is a study that is done with all professionals, the experience of everyone in the daily routine. We are going to join a group, we are going to expose what we are living, our routine, what we can be improving. $\left(\mathrm{E}_{1-6}\right)$

For each change of each vaccine is a Permanent Education. $\left(\mathrm{E}_{2-21}\right)$ 
Health changes a lot, mainly vaccine. So, we are continually following this up and looking for improvements. By looking at what went wrong, looking for a better way to put it into practice. I don't see it like that, which is a need that I have to do bi-weekly, I think it's more daily. Every time I see that I have to change something, I don't have to wait to get the day of Permanent Education. $\left(\mathrm{E}_{4-54}\right)$

\section{Education, qualification and training: means for profes- sional education in service}

Methodologies for permanent education are indicated by the participants:

Don't do a qualification in which I speak and everyone listens, an interactive thing that is periodic and that is with specific themes, not global themes and the person can assimilate that. And also taking theory into practice, always trying to assimilate what is practical in that unity, in the reality of that unity. $\left(\mathrm{E}_{1-15}\right)$

I think it should be inside the vaccination room to have this qualification stronger. $\left(\mathrm{E}_{2-21}\right)$

Addressing smaller issues, rather than addressing the entire vaccine schedule that occupies an entire afternoon and sometimes gets tiring. Approach by vaccine, or by age, even study vaccine cards. $\left(\mathrm{E}_{3-41}\right)$

Refers to the performance of the technical responsible and Permanent Education in the daily service:

Our nurse, she is always empowering us. [...] It makes education permanent as things change. So when the techniques change, it's happening to people, you know? It is constant. Once she does empower there, she brings and empowers people here. We have a Minutes Book, we sign everything. $\left(\mathrm{E}_{2-27}\right)$

It is the responsibility of the unit nurse to train the professional who is present in the daily life room of the vaccine. [...]. So, I think I have to have more training. $\left(\mathrm{E}_{3-36}\right)$

Also expressed are the means available and who to address before the doubts in the vaccination room. In services, manuals are not always available in the vaccination room or online access:

The first person I turn to is the unit nurse. If she doesn't know, if she has any doubt, we have the coordination. [...]. Sometimes when I have some question and I don't find anyone, I call the central post, which the girls have been there for years and years. And we have Telessaúde now, that we can turn to it too. $\left(\mathrm{E}_{2-17}\right)$

First, the books [...] if it's not clear to me, I'm looking for my coordinator, if she doesn't know, we'll call the regional. $\left(\mathrm{E}_{1-23}\right)$

So, in the rural area is difficult because there is no internet, it is very difficult to find the internet. I turn to the manual, first [...] and if it is not enough we try to call for technical reference of immunization [...]. If you can't talk, we use the RSH (Regional Superintendence of Health) and if you also don't have a phone, because sometimes you don't get a phone in the countryside, stop taking the vaccine, stop doing that on that day and then ask for the patient when we are clarified. $\left(\mathrm{E}_{3-38}\right)$

No, not manual, it's just the technical notes they send to people, you know? $\left(\mathrm{E}_{1-25}\right)$

In the vaccination room you have the vaccination manuals, which is always updating. And always the RSH sends a technical note if there is any change. $\left(\mathrm{E}_{4-49}\right)$

It was emphasized the search for knowledge from the professional itself:

We, as professionals, don't have to wait for our referrals to bring the information, we have to look for it ourselves. There are so many sources; there are so many opportunities, so we can run back without waiting for things from the top down. $\left(\mathrm{E}_{1-3}\right)$

I, as the coordinator, my PEH is my own, I am the one who seeks knowledge, because the Regional Health has specific qualifications when it has campaign of influenza vaccination, multivacination, introduction of some immunobiological. $\left(\mathrm{E}_{1-15}\right)$

In the daily routine, the transfer of vaccine information is carried out by the nurse or by the technical reference in immunization:

Sometimes you have a meeting and sometimes you don't. Sometimes it's just a technical note. $\left(\mathrm{E}_{1-7}\right)$

But education here always happens like this: there comes a technical note of vaccine change there, we sit down with the technicians and pass on [...] I would like to have more PEH incentive from the state. Because when it comes to some technical note, they only pass it by email, there isn't a meeting. [...]. Then you have to try to accept it and start putting it into practice. $\left(\mathrm{E}_{3-34}\right)$

The practical-theoretical experience with vaccine contributes to the work in the vaccination room:

Vaccination is daily, it's every day, and it's in practice, because in theory you may know, but in practice it's completely different. So if you have practice, you go away, so the vaccination room is practical all day. $\left(\mathrm{E}_{1-23}\right)$

At first we get a bit insecure due to the pain, the musculature being very small, the nervousness of the mother, the apprehension of the mother. So it is difficult to get started, but over time you will gain experience and you will see that your service is so beneficial, that it's rewarding. $\left(\mathrm{E}_{4-48}\right)$

The training of the professional is attributed as a flaw in relation to theoretical-practical knowledge for acting in the vaccination room:

One thing that we also see a lot is the failure of the training We realize that knowledge about the vaccination room, knowledge about the risks of a wrong vaccine, the benefits 
of getting a vaccine and meeting the vaccine schedule is very superficial. We realize that today the nurse and the nursing technician leave with fear, for fear of vaccine. First thing when the professional enters the health unit, says: OMG, vaccine, I'm afraid, vaccine I have to learn yet, I won't do now, no way. Or on the first mistake, says: no, I don't want to handle with the vaccine anymore. $\left(\mathrm{E}_{1-15}\right)$

Vaccine itself, I just went to learn after I got to work, because college doesn't give you so much information like that. I learned it with the girls here and studying at home. $\left(\mathrm{E}_{3-38}\right)$

Participants in the research address the (lack of) qualification to start vaccine work:

The professional qualification, of me leaving here to go somewhere else, doesn't exist. It was more practical. $\left(\mathrm{E}_{1-25}\right)$

I was trained by another technician, and in the meantime, by the qualifications that the regional provides and by the supervisor. $\left(\mathrm{E}_{3-39}\right)$

No, I wasn't trained. I had to get the manuals and read, I learned applying the vaccine by myself. $\left(\mathrm{E}_{3-40}\right)$

For me to enter there were two qualifications. $\left(\mathrm{E}_{4-47}\right)$

The records of the training, updates and educations carried out in the daily routine of the services were pointed out:

In the old days, I didn't record these trainings that I passed on to them. [...] So, we have recorded the day, the time that began and the time that ended this exchange of experience. $\left(\mathrm{E}_{1-3}\right)$

There is a book that also lists all the meetings she has there, and that she passes to people here. We record everything. $\left(\mathrm{E}_{3-31}\right)$

The scope of Permanent Education in the vaccination room: frequency, participation and daily obstacles

When the periodicity of the Permanent Education actions related to vaccination appears:

Honestly, you don't have a frequency to tell you how it happens. Is it twice a year? Is it every two months? Is very difficult! This year, if it had, it must have been one and it's already seven months. $\left(\mathrm{E}_{1-6}\right)$

So, training even by the secretariat has been a few years, if I'm not mistaken, about three to four years. But there are meetings to review what changes happened, this year there was a meeting to change schedule. But this training it's been a long time. $\left(\mathrm{E}_{2-16}\right)$

The health department, seeing that it has realized this people's existing demand, is also improving [...] it has made these days a training because we have to be constantly following the advances and the changes. $\left(\mathrm{E}_{4-46}\right)$

The need for Permanent Education to be more frequent was pointed out:
I think we are still weak, this issue of PEH fails, I think it should be more continuous, because we have to be always training, exchanging information, knowing new techniques, new vaccines, a general knowledge. I think permanent education is to remain knowledgeable, and sometimes I think about the necessity and importance that is a vaccination room. But I understand that it should be really permanent. $\left(\mathrm{E}_{1-8}\right)$

I think it should have more qualification because we leave there with doubt for not having the opportunity to ask, then you have to keep calling and can't talk. [...] I think it needs a bit of support. $\left(\mathrm{E}_{1-26}\right)$

It had to be always, once a month, every fifteen days, because it is always changing, it had to be this way, constant. $\left(\mathrm{E}_{447}\right)$

The professional evaluates the training, training and education carried out:

There are flaws, of course! We need to have a Permanent Education program inside the municipalities that doesn't happen today, sometimes it does things that are punctual and doesn't focus so well. $\left(\mathrm{E}_{1-15}\right)$

It's no use throwing us there in the vaccination room and letting us. You have to be up to date [...] We are doing the basics that are right, but so, there are many things that could be improving. $\left(\mathrm{E}_{3-44}\right)$

So, these skills they give are fundamental and of great value. I don't know how it is in other places, but the skills that are done here are all well done and well crafted. $\left(\mathrm{E}_{4-49}\right)$

However, not all professionals who work in the vaccination room participate in the qualification/training:

I think every professional should have this right to participate. $\left(\mathrm{E}_{1-24}\right)$

It's like this: I'm a Nursing assistant and the training is for the nurse and the nurse comes and passes it on to us. [...]. If everyone is involved in health, why not do a training for everyone? [...] just the same, now he's going to have a polio campaign, just the nurse that was. Then he has to go, but we have to be present for a day or two training, we will not go. $\left(\mathrm{E}_{2-32}\right)$

Sometimes for the technician and the nurse; sometimes only for the nurse and sometimes for the technician only. They evaluate who will participate there. $\left(\mathrm{E}_{3-44}\right)$

The consequences of lack of qualification, training and education in the vaccination room:

They bring a paper for us to read, there are about ten sheets, it's too lazy to read it all. Sometimes I take it home to read. Sometimes you know what I do? I look at Google, because we don't have a permanent education. $\left(\mathrm{E}_{2-32}\right)$

You need to work on the program question (IS-NIP - Information System of the National Immunization Program), to learn to handle with it. [...]. Because the goals that we have 
not reached, which aren't good, we realize that it has been because of this non-ability to deal with the program. $\left(\mathrm{E}_{2-33}\right)$

Because we get very much like this, receive a technical note, go and pass it on. So there's something like that, each one does it their way, put it to work in their own way. There is no alignment of the teams: Ah, we'll do it like that. $\left(\mathrm{E}_{3-34}\right)$

The obstacles to the periodic non-performance of training, training and education in the vaccination room are:

When there is going to be some training, we have to stop working all day or in the morning or afternoon, and the question of closing the unit is complicated. Sometimes users don't like it, sometimes it comes up to media, you know? They generate a lot of turmoil, understand? That is why I think it doesn't occur so much, because it has to close the Nursing service, and Nursing takes the job, there is no way. $\left(\mathrm{E}_{1-6}\right)$

First of all, I think that a major obstacle of the people who are working in the assistance, is to really find this available time, within even the workload so that people have a specific time to study. $\left(\mathrm{E}_{4-46}\right)$

The interest of the professional or his lack of training, education and training are expressed:

Sometimes professionals disperse, are not interested in that moment, don't have that motivation to be paying attention to what you are showing, don't interact. With modernity today, we have difficulty fixing the attention of the professional. [...]. When doing a training, we have to ask: turn off the cell phones, let's focus on that moment, it's a learning opportunity, we leave the units, we take time that you would be serving the user, providing assistance. Sometimes we just got out of the training, we just said one thing, rephrase that one again, and they call again with the same doubt. Then, why? Because at that moment they weren't paying attention, they were in WhatsApp, looking at their cell phones. $\left(\mathrm{E}_{1-15}\right)$

So, qualification is important and the professional needs to be open to participate, not to think that he or she has stability or that he has been in the service for more than he needs. $\left(\mathrm{E}_{2-29}\right)$

I think nursing assistant and techniques should have more interest, I think the vast majority don't see this as an important thing. Then I don't know if this has to start from me as a nurse to encourage more, or if it has to start from the person himself, because it is for his growth. [...]. So what I find difficult in Permanent Education is this, is you get the nursing technicians and assistants and make them have the same interest. $\left(\mathrm{E}_{3-38}\right)$

\section{DISCUSSION}

It was thought: "Acting in itself is a set of forces that act on who performs it, provoking the formation of the individual protagonist, individual and collective, at the same time that it operates for the production of care, in the case of health. But this is not necessarily transparent and obvious"(16). Not all practitioners can see these minutiae, since "this movement can only be seen by an eye that has been activated for that purpose, and which, on seeing it, identifies it as a movement $^{\prime \prime(16)}$ of PE. However, this is not a necessity, because even without this movement, it is happening as a practice and with its effects. On a daily basis, this process is constitutive of the world of work itself and takes place in the field of various institutional actors, without asking for permission from anyone and without having to be called, as a formative process, to be in fact a place of formation ${ }^{(16)}$.

Thus, PE in the vaccination room should focus on the professional and their daily activities, with their forms and production of knowledge, expression and sharing of acts and actions, through the understanding that the object of vaccination is as the professional "perceives him, interprets the world and expresses his experiences"(17) in the daily life of services.

The fact that the "qualifications" expressed in the results of this study occur in a way that addresses a general rather than a specific theme, makes them less effective. If training activities were organized pedagogically with a differentiated and satisfactory arrangement, they would have greater reach of their objectives. In this way, it traces the reflection about the phenomenon, that is, what, apparently, appears as necessity and forms ${ }^{(17)}$ for $\mathrm{PEH}$ in the daily life of the vaccination room.

It is worth mentioning that the vertical transmission of information and the traditional way of approaching content, not problematizing them, do not demonstrate transformations in the daily services and applied knowledge. It is "the practice that actualizes knowledge and produces it there in the production of the senses in acting"(16). The "technical-scientific update is only one aspect of the qualification of the practices and not its central focus. The training encompasses aspects of the production of subjectivity, the production of technical and thinking skills and the adequate knowledge of SUS"(18).

Nurses' technicians and assistants, participants of this study, ask the nurses the education necessary to perform day-to-day in the vaccine. In this sense, the labor market asks nurses for the knowledge and application of leadership in the coordination of care. Thus, a greater participation in the training actions that address technical issues is justified, since they repeat in the day to day of work and sustain, in the development of the leadership of the team, a work with quality ${ }^{(19)}$.

The professional nurse, as responsible for education for the work of the Nursing team must be aware of the areas to establish a relationship between theory and practice and propose interventions in the face of the doubts that involve the search of the needs, the establishment of goals and objectives, the determination of the planning and evaluation of the results ${ }^{(20)}$.

Despite some advances, the training of health professionals, especially nurses, is still far from care and integral care. Health practices change at all times and the professional is often unable to apprehend and share them. The growing need to provide $\mathrm{PEH}$ for professional training and for strengthening health care in SUS is a challenge ${ }^{(21)}$.

The nurse needs to insert planned supervision of the vaccination room, use the National Immunization Program (PNI) and identify the demands of $\mathrm{PEH}$ in order to develop the potential and qualification of the Nursing team ${ }^{(22)}$. "Depth is on 
the surface of things"(23), all work is linked to the daily routine of the vaccination room and supervision should therefore be understood as part of the process of assisting in the vaccination room, workers, the opportunity where PEH takes place ${ }^{(22)}$.

A case-control study, conducted in Odisha, India, identified a higher level of knowledge among workers who had strategic oversight to improve knowledge and practice in routine immunization. In this research, they related the findings to the success of knowledge sharing from their supervisors ${ }^{(23)}$.

Thus, the reality of Permanent Education in the vaccination room, in this study, is insufficient, infrequent and often not done or is unsatisfactory. The scientific production on the knowledge of the professionals of the vaccination room is insignificant and even scarcer when it is an approach that considers knowledge about all aspects involved in vaccination and that guarantees the fulfillment of the NIP objective. It is observed the non-observation of the continuous qualification of the professionals, since quality assistance must be based on an essential and up-to-date knowledge. It should be emphasized that $\mathrm{PEH}$, however important and no matter how much they may need it, is not frequent, and is considered by professionals to be unsatisfactory for curing the demand for labor ${ }^{(7)}$.

It also contributes to the deficiency and difficulty of the professional to be able to clarify their doubts in their daily work, either due to malfunctions or not working on the internet, or because of the difficulty in making calls for questions such as rural health units ${ }^{(24)}$.

Doubts and difficulties are present in our daily lives in the world of work, and are presented in multiple and ambivalent aspects, arousing feelings varied, many times, from fear, doubt, fear, unbelief and impotence to their manifestations. What is present in the daily life of the vaccination room is "to understand something hidden and evident"(25), because actions are part of a routine, but are modified by constant transformations in knowledge in vaccination.

Thus, the actions of PEH are developed sporadically, going against what is proposed by NPHEP. The quality of the care provided in the vaccination room is directly related to the professionals' knowledge. However, this knowledge is insufficient for the work developed and does not follow the constant changes that occur in the $\mathrm{NIP}^{(7)}$. In this sense, workers with this unsatisfactory qualification can cause errors that compromise the entire process of care in the vaccination room, confidence in the immunization program and lead to adverse events.

In the United States, from January 1, 2000 to December 31, 2013, the Vaccine Adverse Event Reporting System (VAERS) received a total of 311,185 reports of adverse events, with $20,585(7 \%)$ containing events related to vaccination. Reports of vaccination errors increased from $1 \%$ in 2000 to $15 \%$ in $2013^{(26)}$. In Ribeirão Preto, São Paulo State, from January 2007 to June 2012, 2,109,059 doses of vaccines were applied and 186 inadequate procedures were notified, which corresponds to nine incorrect procedures for every thousand doses of vaccines applied ${ }^{(6)}$.

Emphasizing the importance of $\mathrm{PEH}$ and its potential to reorient health practices, management and humanization of services is to bring their meaning and show that, with it, one can achieve a level of quality care, professionals to deal with changes in their daily service ${ }^{(27)}$.

A study carried out in an FHS unit in the city of Itajuípe, Bahia State, identified a lack of $\mathrm{PEH}$ actions and the lack of a local policy that encourages professional qualification and updating $^{(27)}$.

One of the possibilities for PEH is the teaching-service integration $^{(18)}$. The Brazilian Ministry of Health has two current initiatives that allow this integration: Pro-health and Telessaúde, that is, there are also forms external to the team that provide learning of $\mathrm{PEH}$, and health professionals use access to Telessaúde for clarification of doubts ${ }^{(28)}$.

One of the findings of this study was the lack of $\mathrm{PEH}$ for the mid-level team, thus, professionals emphasize the need for greater frequency of educational actions. The restriction of the professionals participating in the actions of PE on vaccination is corroborated by a study that showed that the technicians and assistants of Nursing, the main providers of assistance in vaccination room, do not participate in the educations carried out. This shows that these professionals present difficulties to modify the practices already institutionalized, which emphasizes the commitment of the quality of care provided to the population ${ }^{(29)}$.

The absence of $\mathrm{PEH}$ leads to consequences that will impact the daily work in the vaccination room. For the participants of this study, the lack of PEH leads the professional to clarify their doubts in Google. They also highlight the divergence in daily practices in the vaccine ward for the lack of PEH and the difficulty in using IS-NIP for lack of professional qualification.

Some aspects will interfere with the implementation and development of $\mathrm{PEH}$. Among them are: the insufficient number of human resources and the great demand for health care; the time available for this purpose; the lack of incentive and commitment of the managers; lack of planning of educational actions; and the lack of interest of the professionals in the educations carried out. Such disinterest may be related to managerial issues, such as the lack of planning of educational activities, as well as the lack of base of PEH actions on daily work needs ${ }^{(30)}$. These aspects corroborate with the results of this study.

\section{Study limitations}

In view of the results found, a limitation can be pointed out, considering the cross-analysis of the four cases: the impossibility of attributing effectiveness and efficacy to $\mathrm{PEH}$ in the studied reality, since it is insufficient, infrequent and often not done or is unsatisfactory, despite reports of the PE from the professional itself, informally, from the inside out, from the acting, from the proactivity.

\section{Contributions to nursing and health area}

The results indicate that they are coercive to the reflections about the necessity of PE in the vaccination room in an interactive, periodic way, with punctual and non-global themes for better assimilation. The reality shows the lack of participation of mid-level professionals in these actions and highlights the precision of participating. Thus, they reaffirm the imperative of the nurse acting as facilitator and promoter of $\mathrm{PEH}$, enabling the Nursing team to act and make decisions related 
to the daily care of the vaccination room and to promote safe immunization practices.

\section{FINAL CONSIDERATIONS}

The notions of Permanent Education in the vaccination room are linked to the daily needs of individuals and services, to the indication of being interactive, periodic, with punctual and nonglobal themes for better assimilation. The performance of the technical responsible for the vaccination room was mentioned and attributed to him the mention of the PEH, however, it is not always the professional that the Nursing professionals use in case of vaccination doubts. Means such as: technical notes, vaccination manuals, Google, Telessaúde, Pro-health and books were expressed as knowledge search in vaccination.

The training of the professional is attributed as a flaw in relation to the theoretical-practical knowledge for acting in the vaccination room and that the practical-theoretical experience with vaccine contributes to the daily work. The consequences of the lack of training, training and education in the vaccination room and the obstacles to the non-implementation of PEH are made possible by the overload of work associated with insufficient human resources, the distance of nurses from the vaccination room and the lack of support from higher levels.

The search for knowledge, starting with the professional himself, was inherent in being an active professional actor of the scene of training and work, in a permanent production of knowledge, faced with a reality of $\mathrm{PEH}$ that presents infrequent, non-integrative and insufficient. The context is of a reality where the Permanent Education becomes necessary in front of the complexity and the constant changes of the knowledge in vaccination room.

\section{FUNDING}

Study funded Notice 14/2013 Research Program for SUS (PPSUS) process CBB-APQ-03509-13. Approved and financed with PIBIC / CNPq Scientific Initiation Scholarship.

\section{REFERENCES}

1. França T, Medeiros KR, Belisario SA, Garcia AC, Pinto ICM, Castro JL, et al. Política de Educação Permanente em Saúde no Brasil: a contribuição das Comissões Permanentes de Integração Ensino-Serviço. Ciênc Saúde Colet[Internet]. 2017 [cited 2017 Jul 12];22(6):1817-28. Available from http://www.scielo.br/pdf/csc/v22n6/1413-8123-csc-22-06-1817.pdf

2. Brasil. Ministério da Saúde. Secretaria de Gestão do Trabalho e da Educação na Saúde, Departamento de Gestão da Educação em Saúde. Política Nacional de Educação Permanente em Saúde. Brasília: Ministério da Saúde; 2009.

3. Ceccim RB. Educação permanente em saúde: desafio ambicioso e necessário. Interface Comun Saúde Educ[Internet]. 2005[cited 2017 Mar 28];9(16):161-77. Available from: http://www.scielo.br/pdf/icse/v9n16/v9n16a13.pdf

4. Ceccim RB, Bravin FP, Santos AA. Educação na saúde, saúde coletiva e ciências políticas: uma análise da formação e desenvolvimento para o Sistema Único de Saúde como política pública. Lugar Comum UFRJ[Internet]. 2009[cited 2017 Mar 13];28(1):15980. Available from: http://www.universidadenomade.org.br/userfiles/file/Lugar $\% 20$ Comum/28/13\%20Educacao $\% 20$ na $\% 20$ saude $\% 20$ saude $\% 20$ coletiva $\% 20$ e $\% 20$ ciencias $\% 20$ politicas.pdf

5. Cardoso IM. "Rodas de educação permanente" na atenção básica de saúde: analisando contribuições. Saúde Soc [Internet]. 2012[cited 2017 Jun 21];21(suppl.1):18-28. Available from: http://www.scielo.br/pdf/sausoc/v21s1/02.pdf

6. Brito MFP, Gerin L, Couto ECA, Cunha IS, Corsini MCMM, Gonçalves MC. Caracterização das notificações de procedimentos inadequados na administração de imunobiológicos em Ribeirão Preto, São Paulo, 2007-2012. Epidemiol Serv Saúde [Internet]. 2014 [cited 2017 May 2];23(1):33-44. Available from: http://scielo.iec.pa.gov.br/pdf/ess/v23n1/v23n1a04.pdf

7. Marinelli NP, Carvalho KM, Araújo TME. Conhecimento dos profissionais de enfermagem em sala de vacina: análise da produção científica. Rev Univap [Internet]. 2015 [cited 2017 Jun 20];21(38):2237-53. Available from: http://revista.univap.br/index.php/ revistaunivap/article/view/324/293

8. Oliveira VC, Gallardo MDPL, Cavalcante RC, Arcêncio RA, Pinto IC. Weaknesses of vaccine storage in Primary Healthcare Centers. Rev Bras Enferm [Internet]. 2015 [cited 2017 Jun 19];68(2):291-6. Available from: http://www.scielo.br/pdf/reben/v68n2/ en_0034-7167-reben-68-02-0291.pdf

9. Kartoglu U, Milstien J. Tools and approaches to ensure quality of vaccines throughout the cold chain. Expert Rev Vaccines [Internet]. 2014[cited 2017 May 22];13(7):843-54. Available from: https://www.ncbi.nlm.nih.gov/pmc/articles/PMC4743593/

10. Yakum MN, Ateudjieu J, Walter EA, Watcho PNM, et al. Vaccine storage and cold chain monitoring in the North West region of Cameroon: a cross sectional study. BMC Res Notes [Internet]. 2015 [cited 2017 Jun 19];8:145. Available from: https://bmcresnotes. biomedcentral.com/articles/10.1186/s13104-015-1109-9

11. Araújo ACM, Guimarães MJB, Frias PG, Correia JB. Avaliação das salas de vacinação do Estado de Pernambuco no ano de 2011. Epidemiol Serv Saúde[Internet]. 2013[cited 2017 Jul 13];22(2):255-64. Available from: http://scielo.iec.pa.gov.br/pdf/ess/v22n2/ v22n2a07.pdf

12. Brandão RMS, Castro IO, Lins JMM, Campos MEL, Andrade MS, Guimarães MSA. Fatores relacionados à conservação de vacinas nas unidades básicas de saúde. REUOL[Internet]. 2012 [cited 2017 Jun 20];6(2):332-8. Available from: http://www.ufpe.br/ revistaenfermagem/index.php/revista/article/view/2356/pdf_1018 
13. Yin RK. Estudo de Caso: Planejamento e métodos. 5 ed. Porto Alegre: Bookman; 2015.

14. Maffesoli M. O conhecimento comum: introdução à sociologia compreensiva. Porto Alegre: Sulina; 2010.

15. Bardin L. Análise de conteúdo. Lisboa: Edições 70; 2011.

16. Merhy EE. Educação permanente em movimento: uma política de reconhecimento e cooperação, ativando os encontros do cotidiano no mundo do trabalho em saúde, questões para os gestores, trabalhadores e quem mais quiser se ver nisso. Saúde Redes [Internet]. 2015[cited 2017 Nov 03];1(1):7-14. Available from: http://revista.redeunida.org.br/ojs/index.php/rede-unida/ article/view/309/15

17. Maffesoli M. Elogio da razão sensível. 4 ed. Petrópolis, RJ: Vozes; 2008.

18. Ceccim RB, Feuerwerker LCM. O Quadrilátero da Formação para a Área da Saúde: Ensino, Gestão, Atenção e Controle Social. PHYSIS: Rev Saúde Colet[Internet]. 2004[cited 2017 Nov 03];14(1):41-65. Available from: http://www.scielo.br/pdf/physis/v14n1/ v14n1a04.pdf

19. Salum NC, Prado ML. A educação permanente no desenvolvimento de competências dos profissionais de enfermagem. Texto Contexto Enferm[Internet]. 2014[cited 2017 Jun 23];23(2):301-8. Available from: http://www.scielo.br/pdf/tce/v23n2/pt_01040707-tce-23-02-00301.pdf

20. Fagundes NC, Range AGC, Carneiro TN, Castro LMC, Gomes BS. Educação permanente em saúde no contexto do trabalho da enfermeira. Rev Enferm UERJ [Internet]. 2016 [cited 2017 Jun 23];24(1):11349. Available from: http://www.facenf.uerj.br/v24n1/ v24n1a03.pdf

21. Lavich CRP, Terra MG, Mello AL, Raddatz M, Arnemann CT. Ações de educação permanente dos enfermeiros facilitadores de um núcleo de educação em enfermagem. Rev Gaúcha Enferm [Internet]. 2017 [cited 2017 Jun 23];38(1):1-6. Available from: http:// www.scielo.br/pdf/rgenf/v38n1/0102-6933-rgenf-1983-144720170162261.pdf

22. Oliveira VC, Gallardo PS, Gomes TS, Passos LMR, Pinto IC. Supervisão de enfermagem em sala de vacina: a percepção do enfermeiro. Texto Contexto Enferm[Internet]. 2013[cited 2017 Jul 03];22(4):1015-21. Available from: http://www.scielo.br/pdf/ tce/v22n4/18.pdf

23. Som M, Panda B, Pati S, Nallala S, Anasuya A, Chauhan AS, et al. Effect of supportive supervision on routine immunization service delivery: a randomized post-test study in Odisha. Global J Health Sci [Internet]. 2014[cited 2017 Jun 28];6(6):61-7. Available from: https://www.ncbi.nlm.nih.gov/pmc/articles/PMC4825561/

24. Viegas APB, Carmo RF, Luz ZMP. Fatores que influenciam o acesso aos serviços de saúde na visão de profissionais e usuários de uma unidade básica de referência. Saúde Soc [Internet]. 2015[cited 2017 Jun 20];24(1):100-12. Available from: http://www.scielo. br/pdf/sausoc/v24n1/0104-1290-sausoc-24-1-0100.pdf

25. Maffesoli M. A terra fértil do cotidiano. Rev Famecos [Internet]. 2008 [cited 2017 Jun 28];15(36):5-9. Available from: http:// revistaseletronicas.pucrs.br/ojs/index.php/revistafamecos/article/view/4409/3308

26. Hibbs BF, Moro PL, Miller ER, Shimabukuro TT. Vaccination errors reported to the Vaccine Adverse Event Reporting System, (VAERS) United States, 2000-2013. Vaccine[Internet]. 2015[cited 2017 Jun 23];33(28):3171-78. Available from: https://www. ncbi.nlm.nih.gov/pubmed/2598042926

27. Santos AR, Coutinho ML. Educação Permanente em Saúde: construções de enfermeiros da Estratégia Saúde da Família. Rev Baiana Saúde Pública[Internet]. 2014[cited 2017 Jun 23];38(3):708-24. Available from: http://inseer.ibict.br/rbsp/index.php/rbsp/ article/viewFile/695/pdf_586

28. Cardoso AVL. Avaliação da gestão da Estratégia Saúde da Família por meio do instrumento Avaliação para melhoria da qualidade em município de Minas Gerais, Brasil. Ciênc Saúde Colet [Internet]. 2015 [cited 2017 Jun 23];20(4):1267-84. Available from: http://www.scielo.br/pdf/csc/v20n4/pt_1413-8123-csc-20-04-01267.pdf

29. Oliveira CO, Rennó HMS, Santos YR, Rabelo AFG, Gallardo MPS, Pinto IC. Educação para o trabalho em sala de vacina: percepção dos profissionais de enfermagem. Rev Enferm Cent O Min [Internet]. 2016 [cited 2017 Jun 20];6(3):2331-41. Available from: http://www.seer.ufsj.edu.br/index.php/recom/article/view/1180/1166

30. Signor E, Silva AA, Gomes IEM, Ribeiro RV, Kessler M, Weiler TH, et al. Educação permanente em saúde: desafios para a gestão em saúde pública. Rev Enferm UFSM [Internet]. 2015 [cited 2017 Jun 20];5(1):01-11. Available from: https://periodicos.ufsm.br/ reufsm/article/view/14766/pdf 